\title{
International multicenter examination of MOG antibody assays
}

Neurol Neuroimmunol Neuroinflamm 2020;7:e718. doi:10.1212/NXI.0000000000000718

e718

In the article "International multicenter examination of MOG antibody assays" by Reindl et al., ${ }^{1}$ first published online February 5, 2020, the first sentence of the abstract's Conclusions should read, "Live MOG-IgG CBAs showed excellent agreement for high positive and negative samples at 5 international testing centers." The authors regret the errors.

\section{Reference}

1. Reindl M, Schanda K, Woodhall M, et al. International multicenter examination of MOG antibody assays. Neurol Neuroimmunol Neuroinflamm 2020;7:e674. doi:10.1212/NXI.0000000000000674. 


\title{
Neurology \\ Neuroimmunology \& Neuroinflammation
}

\author{
International multicenter examination of MOG antibody assays \\ Neurol Neuroimmunol Neuroinflamm 2020;7; \\ DOI 10.1212/NXI.0000000000000718
}

This information is current as of March 20, 2020

\section{Updated Information \& \\ Services}

References

Permissions \& Licensing

Reprints including high resolution figures, can be found at:

http://nn.neurology.org/content/7/3/e718.full.html

This article cites 1 articles, 1 of which you can access for free at: http://nn.neurology.org/content/7/3/e718.full.html\#\#ref-list-1

Information about reproducing this article in parts (figures,tables) or in its entirety can be found online at:

http://nn.neurology.org/misc/about.xhtml\#permissions

Information about ordering reprints can be found online: http://nn.neurology.org/misc/addir.xhtml\#reprintsus

Neurol Neuroimmunol Neuroinflamm is an official journal of the American Academy of Neurology.

Published since April 2014, it is an open-access, online-only, continuous publication journal. Copyright $\odot$ 2020 American Academy of Neurology. All rights reserved. Online ISSN: 2332-7812.

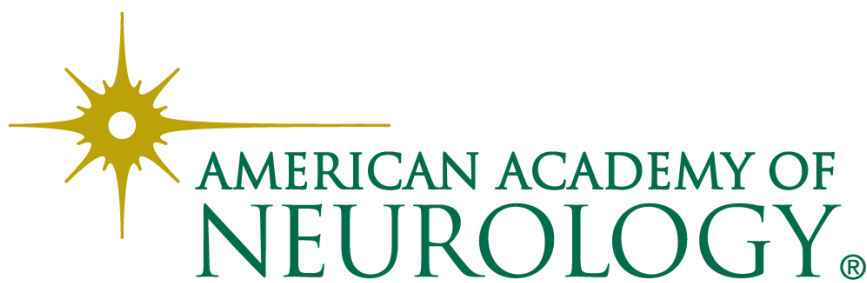

